Hilmi Ozcelik • Yael J. Antebi · David E. C. Cole

Irene L. Andrulis

\title{
Heteroduplex and protein truncation analysis of the BRCA1 185delAG mutation
}

Received: 16 January 1996

\begin{abstract}
We describe a heteroduplex analysis for the detection of the 185 delAG mutation in the BRCA1 gene. The protein truncation test (PTT) has previously been used to identify many of the mutations in BRCA1 that result in premature termination of the protein. However, we were not able to detect the 185 delAG mutation by PTT and suggest that heteroduplex analysis may complement PTT for analysis of BRCA1 mutations. This simple technique may be useful for studies on the prevalence and the penetrance of the $185 \mathrm{del} A G$ mutation.
\end{abstract}

\section{Introduction}

Recent studies have revealed that the nature and the distribution of the mutations in the BRCA1 gene are diverse,

H. Ozcelik · Y. J. Antebi · I. L. Andrulis (凶)

Samuel Lunenfeld Research Institute, Mount Sinai Hospital, Room 865, 600 University Avenue, Toronto M5G 1X5,

ON, Canada

Tel.: +1-416-586-8256; Fax: +1-416-586-8844

H. Ozcelik · I.L. Andrulis

Department of Pathology and Laboratory Medicine,

Mount Sinai Hospital, Toronto, Ontario, Canada

D. E. C. Cole

Department of Clinical Biochemistry, The Toronto Hospital, Toronto, Ontario, Canada

\section{Y. J. Antebi · D. E. C. Cole}

Department of Clinical Biochemistry, University of Toronto, Toronto, Ontario, Canada

\section{E. C. Cole}

Departments of Medicine and Pediatrics, University of Toronto,

Toronto, Ontario, Canada

\section{L. Andrulis}

Departments of Molecular \& Medical Genetics

and Cellular \& Molecular Pathology, University of Toronto,

Toronto, Ontario, Canada

\section{L. Andrulis}

Ontario Cancer Treatment and Research Foundation (OCTRF),

Toronto, Ontario, Canada with no apparent mutational hotspots (Miki et al. 1994; Futreal et al. 1994; Castilla et al. 1994; Simard et al. 1994; Freidman et al. 1994; Shattuck-Eidens et al. 1995). There are, however, some BRCA1 mutations that seem to occur relatively frequently, one of which is the $185 \mathrm{del} A G$ mutation. This is a deletion of an AG dinucleotide in codon 23 of exon 2 of the BRCA1 gene, giving rise to the stop signal at codon 39. Simard et al. (1994) have demonstrated that four families carrying this mutation shared a common haplotype, indicating the importance of ethnic information in screening populations for inherited mutations. The 185 delAG mutation represents $13 \%$ (8/63) of all the mutations characterized to date from studies that involved complete analysis of the coding region of the BRCA1 gene (Shattuck-Eidens et al. 1995). Recently, Struewing et al. (1995) have determined the frequency of this mutation to be approximately $0.9 \%$ (8/858) in Ashkenazi Jewish individuals unselected for the presence of breast cancer or any positive family history of cancer. In the same study, no mutations were detected in 815 individuals unselected for ethnic origin. Studies are required to determine the involvement of this mutation in different breast cancer risk groups and to understand the age-related penetrance of cancer in individuals carrying the 185 delAG mutation. For this reason the development of simple and inexpensive techniques are essential. In this report we describe the analysis of $185 \mathrm{del} A G$ mutation in the BRCA1 gene, by the heteroduplex technique.

\section{Materials and methods}

Given optimal conditions, the technique is sensitive enough to detect a single base substitution. However, due to its efficiency and simplicity, this technique has been much more widely used in detection of deletions or insertions of one or more nucleotides (White et al. 1992; Clay et al. 1991; Sorrentino et al. 1991). The protocol consists of a PCR reaction followed by polyacrylamide gel electrophoresis (PAGE). Heteroduplex formation is carried out by mixing PCR products from mutant and normal samples. On conventional polyacrylamide gels the heteroduplex molecules migrate more slowly than homoduplex molecules. This retardation is the result of mismatch hybridization between normal and deleted or inserted mutant strands. 
A

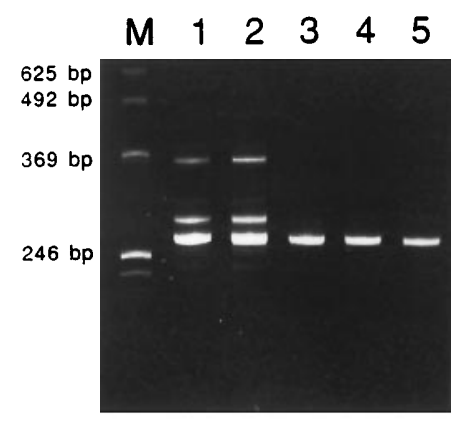

B

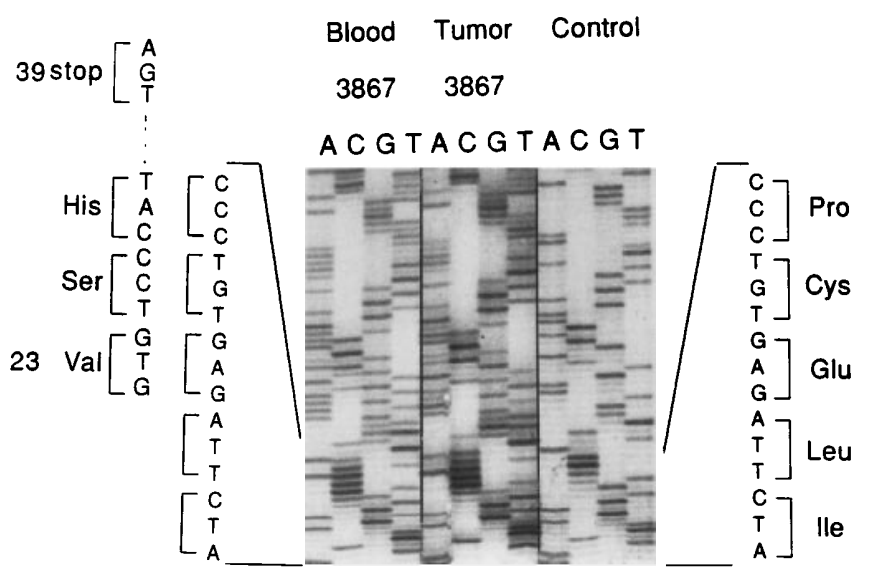

Fig. 1 A Heteroduplex analysis of the 185 delA $G$ mutation in exon 2 of the BRCA1 gene. Blood (lane 1) and tumor sample (lane 2) from patient 3867 with 185 delAG mutation, and control cell lines RPMI 7666 (lane 3), MCF-7 (lane 4), and SK-BR-3 (lane 5) were analyzed by $12 \%$ PAGE. Slowly migrating bands in lanes 1 and 2 are heteroduplex molecules formed by the hybridization of the normal with the mutant allele. Lane $M$ represents the marker $123 \mathrm{bp}$ DNA ladder. B Direct sequence analysis of exon 2 of the BRCA1 gene. Partial nucleotide sequence and corresponding amino acid sequence of blood and tumor DNA sample of case 3867 shows the deletion of an AG dinucleotide in codon 23, resulting in a frameshift leading to a stop codon at position 39

In the present study, the PCR primers, 5'-GAAGTTGTCATTTTATAAACCTTT-3' and 5'-TGCCTTTTCTTCCCTAGTATGT-3 (1), specific to intronic sequences around exon 2 were used to amplify a 250-bp PCR product from genomic DNA. The PCR reaction was carried out using $100 \mathrm{ng}$ genomic tumor or leukocyte DNA in $10 \mathrm{mM}$ Tris- $\mathrm{HCl}(\mathrm{pH} 8.3), 50 \mathrm{mM} \mathrm{KCl}, 0.01 \%$ gelatin, $1.4 \mathrm{mM} \mathrm{MgCl}, 100 \mathrm{mM}$ each deoxyribonucleoside triphosphate (dNTPs), 10 pmol of each primer and 2 units of AmpliTaq DNA polymerase (Perkin-Elmer) in a final volume of $50 \mu \mathrm{l}$. Amplification was performed on a Thermal Cycler 9600 (Perkin-Elmer) for 30 cycles consisting of $20 \mathrm{~s}$ at $94^{\circ} \mathrm{C}, 20 \mathrm{~s}$ at $58^{\circ} \mathrm{C}$ and $30 \mathrm{~s}$ at $72^{\circ} \mathrm{C}$. A 5- $\mu$ l sample of the PCR product was mixed with an equal volume of PCR product from normal control DNA, which was then mixed with $1 \times$ electrophoresis loading buffer $(0.25 \%$ bromophenol blue, $0.25 \%$ xylene cyanol FF, 15\% Ficoll, type 400; Pharmacia). Heteroduplex formation was carried out by denaturing the final mixture for $5 \mathrm{~min}$ at $94^{\circ} \mathrm{C}$ and cooling slowly to room temperature. The samples were then subjected to electrophoresis on $12 \%$ polyacrylamide (29:1 acrylamide:bisacrylamide ratio) gels

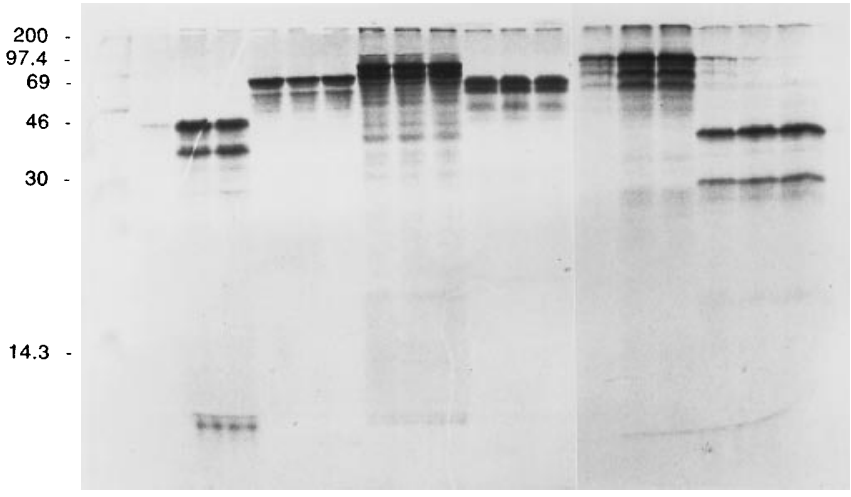

Fig. 2 The protein truncation analysis of the entire coding region of BRCA1 gene. The translational products of sample 3867 (lanes 1, 4, 7, 10, 13, 16), RPMI 7666 (lanes 2, 5, 8, 11, 14, 17) and MCF-7 $(3,6,9,12,15,18)$, covering exons $1-10$ (lanes 1-3), exon 11 (lanes 4-12), exons 12-20 (lanes 13-15) and exons 17-24 (lanes 16-18) of the BRCA1 gene were analyzed on a $17.5 \%$ SDSPAGE. In lane 1, no truncation product, but reduction in the intensity of the normal band due to $185 \mathrm{delAG}$ mutation was observed

at $100-200 \mathrm{~V}$ for $4-8 \mathrm{~h}$. Figure $1 \mathrm{~A}$ demonstrates the heteroduplex formation pattern occurring in both blood and tumor samples from a patient (no. 3867) carrying the 185 delAG mutation. Both blood and tumor DNA from this sample were analyzed by direct sequencing and shown to carry the 185 delAG mutation (Fig. 1B).

The entire coding region of the BRCA1 gene from this sample was also analyzed by a modification of the protein truncation test (PTT) described by Hogervorst et al. 1995. In our study, exons 12-24 of the BRCA1 gene were analyzed with primers that produced smaller products to increase the efficiency of PCR reaction from cDNA. The forward and reverse primers flanking exons 12-20 are 5' - GCTAATACGACTCACTATAGGAACAGACCACCATG-TCACAGTGCAGTGAATTGGAAG-3' and 5'-AGATCTTTCTGTCCTGGG-3', and those flanking exons 17-24 are 5' GCTAATACGACTCACTATAGGAACAGACCACCATGGCTGATGACCCTGAATCTGATCC-3' and 5'-ATCTGGGGTATCAGGTAGGTG-3', yielding PCR products of 1425 and $895 \mathrm{bp}$, respectively. The PCR reaction was carried out in a total volume of $50 \mu$ containing $10 \mathrm{mM}$ Tris- $\mathrm{HCl}(\mathrm{pH} 8.3), 50 \mathrm{mM} \mathrm{KCl}, 1.0 \mathrm{mM}$ $\mathrm{MgCl}_{2}, 0.01 \%$ gelatin, $200 \mu \mathrm{M}$ of each dNTP, $10 \mathrm{pmol}$ of each forward and reverse primers, 2.5 units of AmpliTaq DNA polymerase and $150 \mathrm{ng}$ cDNA. Genomic DNA instead of cDNA was used as a template for the analysis of exon 11 of the BRCA1 gene. Amplification consisted of 40 cycles each of $20 \mathrm{~s}$ at $94^{\circ} \mathrm{C}, 20 \mathrm{~s}$ at $59^{\circ} \mathrm{C}$ and $1 \mathrm{~min} 30 \mathrm{~s}$ at $72^{\circ} \mathrm{C}$. PCR products from tumor and normal control samples were used directly for in vitro protein synthesis by the TnT/T7 coupled rabbit reticulocyte lysate system (Promega). The synthesized protein products were separated by sodium dodecyl sulfate-polyacrylamide gel electrophoresis (SDS-PAGE). The gels were fixed, dried and exposed to autoradiography for 3-12 h.

\section{Results and discussion}

Truncated protein products were not detected in tumor 3867 tested for exon 11 (Fig. 2, lanes 4, 7 and 10), exons 12-20 (lane 13) and exons 17-24 (lane 16), indicating the absence of mutations in these fragments. On the other hand, although equal amounts of PCR products from each sample were used for in vitro translation, the intensity of the band corresponding to the normal protein fragment 
covering exons 2-11 was dramatically lower in the tumor (Fig. 2, lane 1) than in the control samples (lanes 2, 3). This is likely due to a higher fraction of mutant PCR product, which is expected to result in a truncated protein of approximately 39 amino acids in this sample. SDS-polyacrylamide gels with several different concentrations $(14 \%, 17.5 \%$ and $20 \%)$ were run to ensure that small fragments did not run off the gel. However, we did not detect the truncated protein, perhaps due to the limitation of this system in detecting very short proteins. This suggests that reduction in the intensity of the normal protein bands on SDS gels is most likely due to the presence of mutations with undetectable truncated products. The sensitivity of detecting mutations close to the initiation codon might be increased using a forward primer further upstream of the initiation codon for the fragment containing exons 2-11. However, this is not possible for the BRCA1 gene since there is a stop codon in the mRNA sequence a few nucleotides upstream of the initiation codon. Although the protein truncation technique is useful for detecting many of the loss-of-function mutations in the BRCA1 gene, it is not likely to be optimal for analysis of the $185 \mathrm{delAG}$ or other mutations close to the initiation codon.

In this report we have shown that heteroduplex analysis can be used to complement the protein truncation assay for detection of BRCA1 mutations and may be particularly useful for the $185 \mathrm{delAG}$ mutation. In comparison with other techniques such as allele-specific oligonucleotides and DNA sequencing, heteroduplex analysis is nonradioactive, less expensive and relatively simple to perform. Because of these features, heteroduplex analysis is suitable for evaluation of a large number of DNA samples and might be a useful method for studies on the prevalence and the penetrance of the $185 \mathrm{del} A G$ mutation.

Acknowledgements This work was supported by the National Cancer Institute of Canada/Canadian Breast Cancer Research Initiative (I.L.A.) and the Ontario Cancer Genetics Network at the OCTRF.

\section{References}

Castilla LH, Couch FJ, Erdos MR, Hoskins KF, Calzone K, Garber JE, Boyd J, Lubin MB, Deshano ML, Brody LC, Collins FS, Weber BL (1994) Mutations in the BRCA1 gene in families with early-onset breast and ovarian cancer. Nat Genet 8: 387-391
Clay TM, Bidwell JL, Howard MR, Bradley BA (1991) PCR fingerprinting for selection of HLA matched unrelated marrow donors. Lancet 337: 1049-1052

Freidman LS, Ostermeyer EA, Szabo CI, Dowd P, Lynch ED, Rowell SE, King M-C (1994) Confirmation of BRCA1 by analysis of germline mutations linked to breast and ovarian cancer in 10 families. Nat Genet 8: 399-404

Futreal PA, Liu Q, Shattuck-Eidens D, Cochran C, Harchman K, Tavtigan S, Bennet LM, Haugen-Strano A, Swensen J, Miki Y, Eddington K, McClure M, Frye C, Weaver-Feldhaus J, Ding W, Gholami Z, Soderkvist P, Terry L, Jhanwar S, Berchuck A, Iglehart JD, Marks J, Ballinger DG, Barret JC, Skolnick MH, Kamb A, Wiseman R (1994) BRCA1 mutations in primary breast and ovarian carcinomas. Science 266: 120-122

Hogervorst FBL, Cornelis RS, Bout M, Vliet M van, Oosterwijk JC, Olmer R, Bakker B, Klijn JGM, Vasen HFA, Meijers-Heijboer H, Menko FH, Cornelisse CJ, Dunnen JT den, Devilee P, Ommen G-JB van (1995) Rapid detection of BRCA1 mutations by the protein truncation test. Nat Genet 10: 208-212

Miki Y, Swensen J, Shattuck-Eidens D, Futreal PA, Harshman K, Tavigain S, Liu Q, Cochran C, Bennet LM, Ding W, Bell R, Rosenthal J, Hussey C, Tran T, McClure M, Frye C, Hattier T, Phelps R, Haugen-Strano A, Katcher H, Yakumo K, Gholami Z, Shaffer D, Stone S, Bayer S, Wray C, Bogden R, Dayananth P, Ward J, Tonin P, Narod S, Bristow PK, Norris FH, Helvering $\mathrm{L}$, Morrison $\mathrm{P}$, Rosteck $\mathrm{P}$, Lai $\mathrm{M}$, Barret $\mathrm{C}$, Lewis $\mathrm{C}$, Neuhausen S, Cannon-Albright L, Goldgar D, Wiseman R, Kamb A, Skolnick M (1994) A strong candidate for the breast and ovarian cancer susceptibility gene BRCA1. Science 266: 66-71

Shattuck-Eidens D, McClure M, Simard J, Labrie F, Narod S, Couch F, Hoskins K, Weber B, Castilla L, Erdos M, Brody L, Friedman L, Ostermeyer E, Szabo C, King M-C, Jhanwar S, Offit K, Norton L, Gilewski T, Lubin M, Osborne M, Black D, Boyd M, Steel M, Ingles S, Haile R, Lindblom A, Olsson H, Borg A, Bishop T, Solomon E, Radice P, Giovanbattista S, Gayther S, Gayther S, Ponder B, Warren W, Stratton M, Qingyun L, Fujimura F, Lewis C, Skolnick MH, Goldgar DE (1995) A collaborative survey of 80 mutations in the BRCA1 breast and ovarian cancer susceptibility gene. JAMA 273: 535541

Simard J, Tonin P, Durocher F, Morgan K, Rommens J, Gingras S, Samson C, Leblanc J-F, Belanger C, Dion F, Liu Q, Skolnick M, Goldgar D, Shattuck-Eidens D, Labrie F, Narod SA (1994) Common origins of BRCA1 mutations in Canadian breast and ovarian cancer families. Nat Genet 8: 8399-8404

Sorrentino R, Iannicda C, Costanzi S, Chersi A, Tosi R (1991) Detection of complex alleles by direct analysis of DNA heteroduplexes. Immunogenetics 33: 118-123

Struewing JP, Abeliovich D, Peretz T, Avishai N, Kaback M, Collins FS, Brody LC (1995) The carrier frequency of the BRCA1 185delAG mutation is approximately 1 percent in Ashkenazi Jewish individuals. Nat Genet 11: 198-200

White MB, Carvalho M, Derse D, O'Brien SJ, Dean M (1992) Detecting single base substitutions as heteroduplex polymorphisms. Genomics 12: 301-306 